\title{
Anti-wood-fungal Performance of Methanol Extracts of Rhizophora apiculata and $R$. mucronata Barks
}

\author{
Nur Syuhadah Binti Salim, Ismail B. Jusoh,* and Zaini B. Assim \\ Various plant parts of Rhizophora species have been used in the treatment \\ of a variety of diseases and illnesses. However, they have not been tested \\ for antifungal properties related to wood decay fungi, especially the bark \\ extractives. This study examined the methanol $(\mathrm{MeOH})$ crude extracts of \\ $R$. apiculata and $R$. mucronata barks in terms of the amount of extracts \\ obtained and their antifungal properties. The antifungal activities of the \\ crude $\mathrm{MeOH}$ extracts of both species were determined using the agar \\ dilution method. Methanol crude extract from $R$. apiculata and $R$. \\ mucronata were $10.8 \%$ and $15.7 \%$, respectively and were toxic to \\ Chaetomium globosum and Gloeophyllum trabeum at the concentration of \\ $50 \mathrm{mg} / \mathrm{mL}$.
}

\begin{abstract}
Keywords: Rhizophora apiculate; Rhizophora mucronata; Bark extractives; MeOH extracts; Antifungal activities; Agar dilution

Contact information: Faculty of Resource Science and Technology, Universiti Malaysia Sarawak, 94300 Kota Samarahan, Sarawak, Malaysia; *Corresponding author: jismail@unimas.my
\end{abstract}

\section{INTRODUCTION}

Mangrove forests are exceptionally productive ecosystems with diverse plant and wildlife species, and their diversity mainly depends on the amount of precipitation, watershed area, and latitude (Duke et al. 1998; Field et al. 1998; Tomlinson 2016). The organisms, such as plant, bacteria, and fungi, etc., associate with mangrove forests ecologically as their habitat, nursery ground, and coastal protection. They provide tangible and intangible benefits to mankind. Rhizophora species from the mangrove ecosystem are commonly valued for their natural products and ecological services. The woods of Rhizophora species are primarily utilized for firewood and for making charcoal. Rhizophora apiculata is mostly preferred for replanting programmes at mangrove sites in Southeast Asia due to its multitude of uses.

The bark of Rhizophora spp. produces a tannin that can be used for tanning leather. Tannin is also used to strengthen and dye fishing nets, ropes, and lines (Hou and Chan 1997). Traditionally $R$. apiculata and $R$. mucronata extracts are reportedly used to treat diarrhea, nausea, vomiting, typhoid, hepatitis, haematoma, and ulcers (Rowe and Conner 1979; Kokpol et al. 1993; Bandaranayake 2002). Compounds found in R. apiculata include tannins, carotenoids, lipid, $n$-alkanes, minerals, polysaccharides, aliphatic alcohols, steroids, aldehyde, and carboxylic acids (Kokpol et al. 1993; Premanathan et al. 1999a; Bandaranyake 2002). These chemical compounds were obtained from bark, leaves, roots, and seeds extracts during the antiviral, antifungal, antifeedant, and larvicidal activities against human immunodeficiency and antimicrobial activity tests.

Rhizophora mucronata has been tested for antiviral and biotoxicity on fingerlings of fish growth hormone tests on plants where biological compounds including alkaloids, carbohydrates, careotenoids, tannins, saponins, and triterpenes can be found in their bark, 
leaves, roots, and seed extracts (Bandaranayake 2002). Polysaccharides from bark extraction of $R$. mucronata were tested for anti-HIV activity, and the results showed that polysaccharides inhibited the virus from binding with the cells that caused the sickness (Premanathan et al. 1999b). Rhizophora hypocotyls can be eaten as food and medicinal supplements. Ripe $R$. mucronata fruits can be used as an antidiabetic aid (Hardoko et al. 2015). Rhizophora mucronata bark extracts contain $\alpha$-glucosidase inhibitory activity and are also a candidate for antidiabetic function (Lawag et al. 2012).

Bark, flower, fruits, leaves, and roots extracts of $R$. mucronata consist of compounds with properties for treatment of elephantiasis, haematoma, hepatitis, and ulcers (Bandaranayake 2002). Rhizophora mucronata is also a tannin-producing plant that is utilized as a dye (Hou and Chan 1997). Approximately $37 \%$ to 56\% tannin can be found in mangrove's inner bark, of which $11 \%$ to $23 \%$ can be extracted using hot water. The tannins of mangrove are chemically similar to related species and can be exploited in the formulation to form adhesives (Rowe and Conner 1979).

From the preceding paragraphs, there are many valuable potential pharmaceutical products that can be derived from $R$. apiculata and $R$. mucronata. However, little is known about the extractives content and their antifungal activities of $R$. apiculata and $R$. mucronata barks from Malaysia. This study attempts to uncover whether methanol extracts of $R$. apiculata and $R$. mucronata barks from Malaysia have anti-wood-decay fungal activities. The objectives for this study are primarily to: 1.) determine the amount of methanol (MeOH) crude extracts from $R$. apiculata and $R$. mucronata barks, and 2.) to assess anti-wood-decay fungal properties of $\mathrm{MeOH}$ extract. The results may be useful as the extractives may have great potential for yielding useful natural products.

\section{EXPERIMENTAL}

\section{Materials}

Preparation of bark samples

Bark samples of $R$. apiculata and $R$. mucronata were obtained from a mangrove forest near Kampung Temenggong, Matang, Sarawak, Malaysia. Both bark samples were ground using a grinder to produce bark meal. Bark samples were oven-dried at $40{ }^{\circ} \mathrm{C}$ for two days and kept in closed containers for storage.

\section{Preparation of bark extracts}

The solvent extraction method was used for bark extraction as described by Solis et al. (2004) with slight modifications. Rhizophora apiculata and $R$. mucronata bark meals were extracted using $\mathrm{MeOH}$. A total of $1000 \mathrm{~g}$ of bark meal was immersed in $5.0 \mathrm{~L}$ of $\mathrm{MeOH}$ in a separatory funnel at room temperature. After three days, the crude extracts were drained and collected in a round bottom flask. The solvent containing the extracts was weighed and evaporated into dryness using a vacuum rotary evaporator at $35{ }^{\circ} \mathrm{C}$ to obtain crude $\mathrm{MeOH}$ extract. The extraction using $\mathrm{MeOH}$ was repeated two times. All crude extracts were weighed. The total amount of the crude extract obtained was expressed as a percentage.

\section{Methods}

Preparation of fungi inocula 
Gloeophyllum trabeum (brown rot fungus) and Chaetomium globosum (soft rot fungus) were obtained from the Forest Research Institute Malaysia (FRIM; Selangor, Malaysia). Malt extract agar (MEA) was the medium used for fungal growth. Approximately $48 \mathrm{~g}$ of MEA powder was added with $1 \mathrm{~L}$ of distilled water to make a $2 \%$ MEA mixture. Before autoclaving at $121{ }^{\circ} \mathrm{C}$ for $15 \mathrm{~min}$, the MEA mixture was stirred to obtain a well-mixed solution. Subsequently, the MEA solution was poured into sterile disposable Petri dishes and were left to cool to obtain gel plates. Inoculation of G. trabeum and $C$. globosum from stock culture onto agar plates was completed aseptically in a laminar flow hood. Fungi were re-inoculated after one week to prepare pure cultures. Fungal growths were checked frequently to make sure that there was no contamination. If contamination occurred, new inoculation was completed to replace it.

\section{Antifungal assay}

Antifungal assay methods were performed according to the procedure explained by Yen et al. (2008) and Chang et al. (1999, 2000) with slight modifications. The crude $\mathrm{MeOH}$-extracts were diluted with dimethyl sulfoxide (DMSO) to obtain concentrations of $50 \mathrm{mg} / \mathrm{mL}, 25 \mathrm{mg} / \mathrm{mL}, 10 \mathrm{mg} / \mathrm{mL}$, and $5 \mathrm{mg} / \mathrm{mL}$. Each dilution was completed in three replicates. The mixtures were poured into $6-\mathrm{cm}$ Petri dishes. Brown and soft rot fungal plugs from the edge of actively growing cultures were transferred onto the centre of the Petri dishes and were incubated at $27^{\circ} \mathrm{C}$ and $70 \%$ relative humidity for 7 days.

Culture diameters were measured daily. Antifungal indices were calculated when the mycelium fungi reached the edges of the control sample (only DMSO without extractives). Each experiment was conducted three times, and the data were averaged. Growth diameters in all experimental dishes were measured. The antifungal index (AI) was calculated and expressed as percent inhibition using Eq. 1,

$$
A I(\%)=\left(1-D_{\mathrm{a}} / D_{\mathrm{b}}\right) \times 100
$$

where $D_{\mathrm{a}}$ denotes growth diameter in the experimental dish with extract $(\mathrm{cm})$ and $D_{\mathrm{b}}$ is the growth diameter in the control dish $(\mathrm{cm})$.

\section{Statistical Analysis}

The antifungal index (\%) was used for statistical analysis. The Kruskal-Wallis test was performed to determine the toxicity differences of extractives' concentrations obtained from $R$. apiculata and $R$. mucronata barks. The Bonferroni test was performed as a post hoc test. Kruskal-Wallis and Bonferroni tests were conducted using SPSS version 24 (IBM Corp., New York, USA 2016). Kruskal-Wallis was used because the data were not normally distributed due to small sample size $(n=9)$ for each experiment (Weaver et al. 2017).

\section{RESULTS AND DISCUSSION}

\section{Crude Methanol Extractives from Bark}

The results showed that the average yield of methanol extract from $R$. mucronata was more than that from $R$. apiculata (Table 1), suggesting that $R$. mucronata contained more methanol-soluble compounds than $R$. apiculata. The yields of methanol-soluble extractives were considered high, noting that it is common in tropical woods to have extractives of more than 10\%, especially from bark (Shmulsky and Jones 2011). The 
overall amount of both lipophilic and hydrophilic components can reach up to $20 \%$ to $40 \%$ of the dry weight of bark (Suki and John 2001; Yang and Jaakkola 2011).

Table 1. Mean Yield of Crude Methanol Extracts of $R$. apiculata and $R$. mucronata Barks Based on Dry Weight

\begin{tabular}{|c|c|}
\hline Bark Sample & $\begin{array}{c}\text { Mean Yield of Crude } \\
\text { Extract (\%) }\end{array}$ \\
\hline$R$. apiculata & $10.8 \mathrm{a}^{*}$ \\
\hline$R$. mucronata & $15.7 \mathrm{~b}$ \\
\hline
\end{tabular}

*Mean followed by different letter indicates significant difference at $5 \%$ level

\section{Anti-wood-decay Fungal Activities of Methanol Bark Extract}

Growth of test fungi reached the edge of the 6-cm Petri dish in 7 days (Fig. 1). However, with the introduction of bark extracts into the media the fungi did not reach the edge, and when a higher concentration of extract was used the fungal diameter became smaller. The effect of increasing concentration of crude $\mathrm{MeOH}$-extracts obtained from $R$. apiculata and $R$. mucronata barks on fungal diameter growth is shown in Table 2 . The growth of test fungi significantly reduced as the concentration of bark extracts increased. The growth of $C$. globosum was totally inhibited at $50 \mathrm{mg} / \mathrm{mL}$ of $R$. mucronata bark extract.

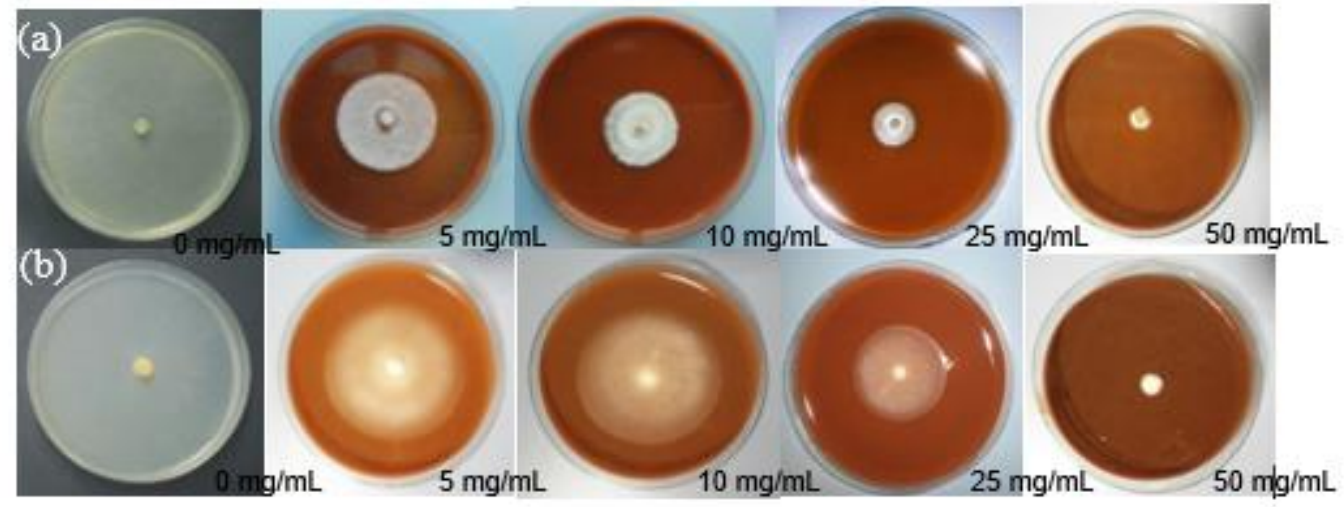

Fig. 1. Fungal growth at various extract concentrations (left to right): $0,5,10,25$, and $50 \mathrm{mg} / \mathrm{mL}$ : (a) Chaetomium globosum in Petri dishes of $R$. apiculata bark extracts; and (b) Gloeophyllum trabeum in Petri dishes of $R$. mucronata bark extracts

The results of antifungal activities of bark crude extracts obtained from $R$. apiculata and $R$. mucronata bark are shown in Table 3. Antifungal activities were measured using antifungal index $(\%)$ where it shows the inhibitory effect at each concentration, indicating that the higher indices exhibited a stronger inhibitory effect. Antifungal index increased with increasing concentrations of methanol extracts of $R$. apiculata and $R$. mucronata. Antifungal indices of $R$. apiculata were higher than $R$. mucronata at concentrations from $5 \mathrm{mg} / \mathrm{mL}$ to $25 \mathrm{mg} / \mathrm{mL}$. However, the $50 \mathrm{mg} / \mathrm{mL}$ extract concentration of $R$. mucronata bark presented the highest AI (Table 3). Methanol crude extract of $R$. apiculata and $R$. mucronata barks showed good inhibitory effects on $C$. globosum and $G$. trabeum at 50 $\mathrm{mg} / \mathrm{mL}$. These results suggested that extracts of $R$. apiculata and $R$. mucronata barks have the ability to resist these two wood decay fungal species. Not all methanol bark extracts are toxic to wood decaying fungi, for instance out of 15 Malaysian timber species only 
three species, Neobalanocarpus heimii, Cinnamomum porrectum, and Shorea assamica, of bark extracts were toxic to G. trabeum and Pycnoporus sanguineus (Kawamura et al. 2010).

Table 2. Mean Diameter (cm) of Growth of C. globosum and G. trabeum at Various Concentrations of $R$. apiculata and $R$. mucronata Bark Extracts After Seven Days of Incubation

\begin{tabular}{|c|c|c|c|c|}
\hline \multirow{2}{*}{$\begin{array}{c}\text { Concentration } \\
(\mathrm{mg} / \mathrm{mL})\end{array}$} & \multicolumn{2}{|c|}{ R. apiculata } & \multicolumn{2}{c|}{ R. mucronata } \\
\cline { 2 - 5 } & $\begin{array}{c}\text { Chaetomium } \\
\text { globosum }\end{array}$ & $\begin{array}{c}\text { Gloeophyllum } \\
\text { trabeum }\end{array}$ & $\begin{array}{c}\text { Chaetomium } \\
\text { globosum }\end{array}$ & $\begin{array}{c}\text { Gloeophyllum } \\
\text { trabeum }\end{array}$ \\
\hline $0^{*}$ & $5.6 \mathrm{~d}^{\star *}$ & $5.8 \mathrm{~d}$ & $6 \mathrm{~d}$ & $6.0 \mathrm{c}$ \\
\hline 5 & $4.3 \mathrm{c}$ & $4.2 \mathrm{c}$ & $4.2 \mathrm{c}$ & $5.6 \mathrm{c}$ \\
\hline 10 & $3.5 \mathrm{~b}$ & $3.1 \mathrm{~b}$ & $4.9 \mathrm{c}$ & $5.7 \mathrm{c}$ \\
\hline 25 & $3.0 \mathrm{ab}$ & $2.3 \mathrm{a}$ & $3.0 \mathrm{~b}$ & $4.0 \mathrm{~b}$ \\
\hline 50 & $1.1 \mathrm{a}$ & $1.9 \mathrm{a}$ & $0.0 \mathrm{a}$ & $1.1 \mathrm{a}$ \\
\hline
\end{tabular}

${ }^{*}$ Control sample without extractives;

** Mean followed by different letter in each fungus indicates significant difference at $5 \%$ level;

Each experiment was performed 3 times, 3 replicates each time, and the data were averaged $(n=9)$

Table 3. Antifungal Indices of Various $R$. apiculata and $R$. mucronata Bark Extract Concentrations Against C. globosum and G. trabeum

\begin{tabular}{|c|c|c|c|}
\hline \multirow{2}{*}{ Fungi } & $\begin{array}{c}\text { Concentration } \\
(\mathrm{mg} / \mathrm{mL})\end{array}$ & \multicolumn{2}{|c|}{ Antifungal Index (\%) } \\
\cline { 2 - 4 } & 5 & $R$. apiculata & $R$. mucronata \\
\hline \multirow{3}{*}{ Chaetomium globosum } & 10 & $18.9 \mathrm{ab}^{*}$ & $16.8 \mathrm{a}$ \\
\cline { 2 - 4 } & 25 & $33.4 \mathrm{~cd}$ & $22.2 \mathrm{abc}$ \\
\cline { 2 - 4 } & 50 & $73.2 \mathrm{~d}$ & $29.5 \mathrm{bc}$ \\
\cline { 2 - 4 } Gloeophyllum trabeum & 5 & $30.0 \mathrm{e}$ & $100.0 \mathrm{f}$ \\
\cline { 2 - 4 } & 10 & $47.8 \mathrm{bc}$ & $7.3 \mathrm{a}$ \\
\cline { 2 - 4 } & 25 & $61.7 \mathrm{~d}$ & $35.0 \mathrm{a}$ \\
\cline { 2 - 4 } & 50 & $69.2 \mathrm{~d}$ & $82.3 \mathrm{e}$ \\
\hline
\end{tabular}

${ }^{\star}$ Mean followed by different letter in each fungus indicates significant difference at $5 \%$ level;

Data collected after 7 days of incubation;

Each experiment was performed 3 times, 3 replicates each time and the data were averaged $(n=9)$

The reduction in growth of fungi as extractive concentration increases has been observed in many antifungal activity studies. For example, methanol extracts of Eusideroxylon zwageri and Potoxylon melagangai heartwood achieved an antifungal index against Trametes versicolor, G. trabeum, and C. globosum of more than $90 \%$ at the concentration of $50 \mathrm{mg} / \mathrm{mL}$ (Jusoh et al. 2019). Essential oil of Eucalyptus camaldulensis leaves recorded a 100\% antifungal index against $C$. globosum at the concentration of 10 $\mathrm{mg} / \mathrm{mL}$ (Siramon et al. 2013). Methanol extract of Juniperus foetidissima heartwood recorded $78 \%$ antifungal activity at concentration of $500 \mathrm{ppm}$ (Ateş et al. 2015). 


\section{CONCLUSIONS}

1. Increased concentrations of crude extracts from mangrove bark significantly increased the inhibitory effect against $C$. globosum and G. trabeum wood-decay fungi.

2. Crude methanol extracts of $R$. apiculata and $R$. mucronata barks inhibited the growth of $C$. globosum and $G$. trabeum fungal species at $50 \mathrm{mg} / \mathrm{mL}$ concentration.

\section{ACKNOWLEDGMENTS}

The authors are thankful to the UNIMAS Tun Zaidi Chair (F/07/TZC/1594/2017) for supporting this study.

\section{REFERENCES CITED}

Ateş, S., Gür, M., Özkan, O. E., Akça, M., Olgun, C., and Güder, A. (2015). 'Chemical contents and antifungal activity of some durable wood extractives vs. Pleurotus ostreatus," BioResources 10(2), 2433-2443. DOI: 10.15376/biores.10.2.2433-2443

Bandaranayake, W. M. (2002). "Bioactivities, bioactive compounds and chemical constituents of mangrove plants," Wetlands Ecology and Management 10(6), 421452.

Chang, S. T., Wang, S. Y., Wu, C. L., Chen, P. F., and Kuo, Y. H. (2000). "Comparison of the antifungal compounds of the antifungal activity of cadinane skeletal sesquiterpenoids from Taiwania heartwood," Holzforshung 54(3), 241-245. DOI: 10.1515/HF.2000.041

Chang, S. T., Wang, S. Y., Wu, C. L., Su, Y. C., and Kuo, Y. H. (1999). “Antifungal components in the ethyl acetate soluble fraction of the extractives of Taiwania heartwood," Holzforshung 53(5), 487-490. DOI: 10.1515/HF.1999.080

Duke, N. C., Ball, M. C., and Ellison, J. C. (1998). "Factors influencing the biodiversity and distributional gradients in mangrove," Global Ecology and Biogeography Letters 7(1), 27-47. DOI: 10.2307/2997695

Field, C. B., Osborn, J. G., Hoffman, L. L., Polsenberg, J. F., Ackerly, D. D., Berry, J. A., Björkman, O., Held, A., Matson, P. A., and Mooney, H. A. (1998). "Mangrove biodiversity and ecosystem function," Global Ecology and Biogeography Letters 7(1), 3-14. DOI: 10.2307/2997693

Hardoko, S. E., Puspitasari, Y. E., and Amalia, R. (2015). "Study of ripe Rhizophora mucronata fruit flour as functional food for antidiabetic," International Food Research Journal 22(3), 953-959.

Hou, D., and Chan, H. T. (1997). "Rhizophora apiculata Blume," in: Plant Resources of South-East Asia No. 11. Auxiliary Plants, I. Faridah Hanum, and L. J. G. van der Maesen (eds.), Backhuys Publishers, Leiden, Netherlands, pp. 220-223.

Jusoh, I., Ping, S. S., and Assim, Z. (2019). "Toxicity of dichloromethane and methanolsoluble extractives from Esideroxylon zwageri and Potoxylon melagangai heartwoods," Transactions on Science and Technology 6(1-2), 86-94.

Kawamura, F., Ramle, S. F. M., Sulaiman, O., Hashim, R., and Ohara, S. (2010). "Antioxidant and antifungal activities of extracts from 15 selected hardwood species 
of Malaysian timbers," Holz als Roh- und Werkstoff 69(2), 207-212. DOI:

10.1007/s00107-010-0413-2

Kokpol, U., Chavasiri, W., Chittawong, V., Bruce, M., Cunningham, G. N., and Miles, D. H. (1993). "Long chain aliphatic alcohols and saturated carboxylic acids from heartwood of Rhizophora apiculata," Phytochemistry 33(5), 1129-1131. DOI: 10.1016/0031-9422(93)85036-Q

Lawag, I. L., Aguinaldo, A. M., Nahed, S., and Mosihuzzaman, M. (2012). " $\alpha$-Glucosidase inhibitory activity of selected Philippine plants," Journal of Ethnopharmacology 144(1), 217-219. DOI: 10.1016/j.jep.2012.08.019

Premanathan, M., Arakaki, R., Izumi, H., Kathiresan, K., Nanako, M., Yamamoto, N., and Nakashima, H. (1999a). "Antiviral properties of a mangrove plant, Rhizophora apiculata Blume, against human immunodeficiency virus," Antiviral Research 44(2), 113-122. DOI: 10.1016/S0166-3542(99)00058-3

Premanathan, M., Kathiresan, K., Yamamoto, N., and Nakashima, H. (1999b). "In vitro anti human immunodeficiency virus activity of polysaccharides from Rhizophora mucronata Poir," Bioscience, Biotechnology, and Biochemistry 63(7), 1187-1191.

Rowe, J. W., and Conner, A. H. (1979). Extractives in Eastern Hardwoods - A Review, U.S. Department of Agriculture Forest Products Laboratory, Madison, WI, USA.

Shmulsky, R., and Jones, P. D. (2011). Forest Products and Wood Science: An Introduction, $6^{\text {th }} E d$., Wiley-Blackwell, West Sussex, UK.

Siramon, P., Ohtani, Y., and Ichiura, H. (2013). "Chemical composition and antifungal property of Eucalyptus camaldulensis leaf oils from Thailand," Records of Natural Products, 7(1), 49-53.

Solis, C., Becerra, J., Flores, C., Robledo, J., and Silva, M. (2004). “Antibacterial and antifungal terpenes from Pigerodendron uviferum florin," Journal of Chilean Chemical Society 49(2), 157-161. DOI:dx.doi.org/10.4067/S071797072004000200010.

Suki, C., and John, H. (2001). Wood Extractive Concentration and SEM Examination of Pretreated Southern Yellow Pine Wood Chips with Blue-Stain Fungi for Mushroom Production, International Research Group on Wood Preservation, IRG/WP01-10407, Nara, Japan.

Tomlinson, P. B. (2016). The Botany of Mangroves ( $2^{\text {nd }}$ Ed.), Cambridge University Press, New York City, NY, USA.

Weaver, K. F., Morales, V., Dunn, S. L., Godde, K., and Weaver, P. F. (2017). An Introduction to Statistical Analysis in Research: With Applications in Biological and Life Sciences, John Wiley \& Sons, Inc., Hoboken, NJ, USA.

Yang, G., and Jaakkola, P. (2011). Wood Chemistry and Isolation of Extractives from Wood: Literature Study for BIOTULI Project, Saimaa University of Applied Sciences, Lappeenranta, Finland.

Yen, T. B., Chang, H. T., Park, D. S., Xu, M. Z., Oh, H. W., Song, K. B., and Lee, W. S. (2008). "Antifungal properties of ethanolic extract and its active compounds from Calocedius macrolepis var. formosana (florin) heartwood," Bioresource Technology 99, 4871-4877. DOI: 10.1016/j.biortech.2007.09.037

Article submitted: August 2, 2019; Peer review completed: October 19, 2019; Revised version received and accepted: April 9, 2020; Published: April 15, 2020.

DOI: $10.15376 /$ biores.15.2.4143-4149 